\title{
Insulation, Asbestos, Smoking Habits, and Lung Cancer Cell Types
}

\author{
Joshua E. Muscat, MPH, Steven D. Stellman, PhD, and Ernst L. Wynder, MD
}

\begin{abstract}
The association between occupational exposure to asbestos and histological type of lung cancer was analyzed in a multicenter hospital-based case-control study $(2,871$ male cases and 5,240 male controls) conducted from 1981-1991. Twenty-two percent of cases and $18 \%$ of controls were employed in asbestos-related occupations for at least 1 year. Most of these asbestos jobs were in the construction field. The odds ratio (OR) among current smokers was 1.0 [95\% confidence intervals (CI) 0.9 to 1.3]; for exsmokers, the OR was 1.4 (95\% CI 1.1 to 1.6). In contrast, $10 \%$ of cases and $5 \%$ of controls self-reported that they were chronically exposed to asbestos for at least 1 year. Self-reported asbestos exposure was significantly related to all lung cancer cell types among smokers and ex-smokers, although a trend in the ORs with duration of selfreported exposure was not found for current smokers. Among 48 cases and 52 controls reporting distinct exposure to building insulation, the OR was 2.2 (95\% CI 1.2 to 4.3 ) for current smokers, and 1.8 (95\% CI 0.9 to 3.6) for ex-smokers, compared to subjects who were not exposed to building insulation and asbestos. A nonsignificant association with self-reported exposure to asbestos was observed for a small number of never smokers (eight of 83 nonsmoking cases, $\mathrm{OR}=2.0,95 \% \mathrm{CI} 0.9$ to 4.6 ). When examining these results and their causal implications, possible misclassification and reporting biases need to be considered. (c) 1995 Wiley-Liss, Inc.
\end{abstract}

Key words: asbestos, occupation, lung cancer, smoking, epidemiology, pathology

\section{INTRODUCTION}

Exposure to heavy concentrations of asbestos increases the already high risk of lung cancer among cigarette smokers. An excess lung cancer risk or elevated mortality rate has been found among smokers who were employed in occupations such as shipbuilding [Blot et al., 1978, 1980], asbestos mining and milling [Rubino et al., 1979], asbestos factory work [Selikoff et al., 1980; Acheson et al., 1984; Berry et al., 1985], and insulation trades [Hammond et al., 1979] (Table I).

There is less information on the risk of lung cancer among men who smoked and were employed in jobs such as construction and carpentry. These jobs have likely entailed relatively lower levels of asbestos exposure. This report describes the asbestos-associated risk of lung cancer in a large case-control study. We examined the lung

Division of Epidemiology, American Health Foundation, New York, NY.

Address reprint requests to Joshua E. Muscat, Division of Epidemiology, American Health Foundation, 320 East 43rd Street, New York, NY 10017.

Accepted for publication November 24, 1993.

(C) 1995 Wiley-Liss, Inc. 
TABLE I. Published Studies of Asbestos-Exposed Workers, Smoking, and Lung Cancer

\begin{tabular}{llcc}
\hline Author/year & Location or type & $\begin{array}{c}\text { No. exposed } \\
\text { cases }\end{array}$ & $\begin{array}{c}\text { RR (SMR) } \\
\text { for ""never" } \\
\text { smokers }\end{array}$ \\
\hline Blot et al., 1980 & Shipyard/Virginia & $95(25)^{\mathrm{a}}$ & $1.9^{\mathrm{c}, \mathrm{d}}$ \\
Blot et al., 1978 & Shipyard/Georgia & $95(11)$ & $1.3^{\mathrm{c}, \mathrm{d}}$ \\
Martischnig et al., 1977 & Case-control & $58(7)$ & $1.1^{\mathrm{c}}$ \\
Pastorino et al., 1984 & Case-control & $131(2)$ & $2.8^{\mathrm{c}, \mathrm{d}}$ \\
Acheson et al., 1984 & Amosite factory & $57(1)$ & $3.0^{\mathrm{e}, \mathrm{f}}$ \\
Selikoff et al., 1980 & Amosite factory & $60(3)$ & 15.0 \\
Hammond et al., 1979 & Insulation workers & $276(4)$ & 5.7 \\
Berry et al., 1985 & Asbestos factory & & \\
& 1971-1980 & $64(1)$ male & $6.2^{\mathrm{g}}$ \\
& & $15(3)$ females & 12.5 \\
Rubino et al., 1979 & $1960-1970$ & $37(0)$ female & - \\
\hline
\end{tabular}

${ }^{a}$ Numbers in parentheses indicate number of nonsmoking cases exposed to asbestos.

'Relative risks (RR, SMR) are for nonsmoking asbestos-exposed cases compared to nonsmoking controls or standard population.

Includes light and ex-smokers.

dEstimated.

'Smoking habits obtained from cases and next of kin.

fSmoking habits obtained from medical records.

${ }^{g}$ Never smokers had the highest risk of lung cancer.

cancer risk among subjects who worked in a variety of asbestos-related jobs such as construction, electrical work, plumbing, welding, and automobile mechanics. The lung cancer risk is also examined by smoking habits including current and former cigarette smoking, and never having smoked. In addition, since peripheral lung tumors such as adenocarcinoma and large cell carcinoma are less strongly associated with tobacco smoke than central tumors but may be differentially affected by occupational risk factors [El-Torky et al., 1990; Morabia and Wynder, 1991; Devesa et al., 1991], the effect of asbestos on lung cancer was also examined by the tumor site within the lung.

\section{MATERIALS AND METHODS}

There were 2,871 newly diagnosed male lung cancer cases interviewed between 1981 and 1991 as part of a larger case-control study of tobacco-related cancers. This study has been previously described [Morabia et al., 1991]. In brief, incident cases of men and women who were diagnosed with lung cancer were interviewed by trained personnel in nine hospitals in New York, Michigan, Illinois, and Pennsylvania. Eligible controls included male patients with conditions unrelated to tobacco etiology. The major control diagnoses were nonmalignant conditions (39\%), colorectal cancer $(14 \%)$, prostate cancer $(11 \%)$, sarcomas and lymphomas $(9 \%)$, benign neoplasms $(7 \%)$, and benign prostatic hypertrophy $(6 \%)$.

In the overall study, controls were interviewed in the same hospital as the case and within 2 months of the case interview. Controls were of similar ages as the cases ( \pm 5 years). For the current analysis, lung cancer cases were compared to the entire control series of 5,240 men. 
Information on lung cancer morphology was abstracted from hospital pathology reports. Categories of cell types included squamous, epidermoid, small cell, oat cell, large cell, adenocarcinoma, mixed, and unspecified histologies. Cases that had tumors arising from the pleura were excluded from the study.

The questionnaire included detailed questions on demographics, tobacco smoking, employment history, and occupational exposures. Two different versions of the questionnaire were used during the study period. From 1981 to 1985 , data were obtained on the most usual adult occupation. In the more recent version, subjects were asked to give their job titles, and the dates and duration of employment for all jobs held for 1 or more years. Occupations involving likely asbestos exposure were determined according to published reports in the medical or government literature. These jobs include asbestos factory workers, shipyard employment, insulation work, construction (e.g., electricians, carpenters, plasterers, painters, pipe fitters, plumbers, cement finishers), stationary engineers, railroad workers, rubber plant workers, firefighters and fire chiefs, mine and textile operatives, and automobile and heavy equipment mechanics [Muscat and Wynder, 1991; McDonald and McDonald, 1980; Nicholson et al., 1982; Young et al., 1981; Teta et al., 1983; Mancuso, 1983; Schenker et al., 1986; Rodelsperger et al., 1986; Quinn et al., 1987; Talcott et al., 1989; Department of Labor, 1990]. Subjects were asked separate questions on whether they had been exposed to asbestos dust on the job for at least $8 \mathrm{hr}$ a week for 1 or more years. The later version of the questionnaire included a separate question on exposure to building insulation.

Lifetime exposure to tobacco smoke was assessed according to current smoking status, number of cigarettes smoked per day, and number of years since quitting (for ex-smokers). Never smokers included subjects who smoked fewer than 100 cigarettes; current smoking was defined as smoking one or more cigarettes per day. Ex-smokers were defined as having quit smoking for at least 1 year.

The data were analyzed by comparing cases to controls with the same smoking habits. When assessing a dose-response relationship with the duration of asbestos exposures in terms of years, the asbestos exposure variables were categorized according to the quartile distribution within the control group. Separate analyses were conducted for cases with central tumors (predominantly squamous, small, and oat cell carcinoma), peripheral tumors (adenocarcinoma and large cell carcinoma), and all cell types combined (including other, mixed, and unknown histologies). Odds ratios (OR) adjusted for potentially confounding variables were calculated using unconditional multiple logistic regression analysis on SAS statistical software [SAS User's Guide, 1985].

\section{RESULTS}

The mean age of both cases and controls was 59 years, and over $90 \%$ of both groups were white subjects (Table II). Cases had fewer years of formal schooling than controls (mean, 12.3 years and 13.4 years). There was a higher proportion of Catholic men in the case group than in the control group (51\% and $43 \%$ ). More cases with central lung tumors (squamous, small, and oat cell cancers) ever smoked cigarettes and smoked more cigarettes per day compared to cases with peripheral lung tumors (adenocarcinoma and large cell carcinoma). Among subjects who quit smoking cigarettes, recent quitters ( $\leq 10$ years) were more likely to have had central lung cancer 
TABLE II. Basic Demographic Characteristics of 2,871 Male Cases of Lung Cancer and 5,240 Hospital Controls, 1981-1991

\begin{tabular}{|c|c|c|c|c|c|c|c|c|}
\hline & \multicolumn{6}{|c|}{ Lung cancer cases } & & \\
\hline & \multicolumn{2}{|c|}{ Central } & \multicolumn{2}{|c|}{ Peripheral } & \multicolumn{2}{|c|}{ Other } & \multicolumn{2}{|c|}{ Controls } \\
\hline & \multicolumn{2}{|c|}{1,347} & \multicolumn{2}{|c|}{1,156} & \multicolumn{2}{|c|}{368} & \multicolumn{2}{|c|}{5,240} \\
\hline \multicolumn{9}{|l|}{ Age } \\
\hline$<44$ & 71 & 7.9 & 106 & 9.2 & 26 & 7.1 & 415 & 7.9 \\
\hline $44-54$ & 252 & 18.7 & 251 & 21.7 & 70 & 19.0 & 1,051 & 20.1 \\
\hline $55-64$ & 542 & 40.2 & 447 & 38.7 & 144 & 39.1 & 2,111 & 40.3 \\
\hline $65-74$ & 420 & 31.2 & 304 & 26.3 & 107 & 29.1 & 1,481 & 28.3 \\
\hline$\geq 75$ & 182 & 3.5 & 62 & 4.6 & 48 & 4.2 & 182 & 3.5 \\
\hline \multicolumn{9}{|c|}{ Years of education } \\
\hline$<12$ & 512 & 38.2 & 326 & 28.3 & 118 & 32.1 & 1,254 & 24.0 \\
\hline 12 & 389 & 29.0 & 325 & 28.2 & 104 & 28.3 & 1,341 & 25.7 \\
\hline $13-15$ & 191 & 14.2 & 207 & 18.0 & 54 & 14.7 & 884 & 16.9 \\
\hline$\geq 16$ & 250 & 18.6 & 293 & 25.5 & 92 & 25.0 & 1,747 & 33.4 \\
\hline \multicolumn{9}{|l|}{ Race } \\
\hline White & 1,218 & 90.4 & 1,052 & 91.0 & 338 & 91.9 & 4,862 & 92.8 \\
\hline Black/other & 129 & 9.6 & 104 & 9.0 & 30 & 8.2 & 378 & 7.2 \\
\hline \multicolumn{9}{|l|}{ Smoking habits } \\
\hline Never & 15 & 1.0 & 53 & 4.6 & 15 & 4.1 & 1,260 & 24.1 \\
\hline Current & 786 & 58.3 & 637 & 55.1 & 209 & 56.8 & 1,354 & 25.8 \\
\hline Ex-smokers & 516 & 38.3 & 450 & 38.9 & 139 & 37.8 & 2,237 & 42.7 \\
\hline Cigar/pipe & 30 & 2.2 & 16 & 1.4 & 5 & 1.4 & 389 & 7.4 \\
\hline
\end{tabular}

than peripheral lung cancer. For both cases and controls, smoking habits were unrelated to either employment in asbestos-related occupations or self-reported exposure to asbestos dust.

\section{Asbestos Occupations}

Table III shows the number of cases and controls that were employed in asbestos-related occupations. The majority of these subjects worked as construction workers and supervisors, carpenters, plumbers/pipe fitters, electricians, welders, building maintenance personnel, automobile mechanics, and other transportation equipment mechanics. Only one case was exposed to asbestos in a Navy shipyard.

From 1980 to 1985 , the questionnaire elicited information on the most usual adult occupation. Sixteen percent of cases and $12 \%$ of controls who were interviewed in this time period were employed in asbestos occupations. From 1986 to 1991, the questionnaire collected information on lifetime employment. Thirty percent of cases and $27 \%$ of controls who were interviewed in this time period worked in asbestos occupations. For the whole study period, $22 \%$ of cases and $18 \%$ of controls worked in asbestos-related occupations; the average duration of employment in these jobs was 23 and 21 years, respectively (Table IV). [A higher proportion of controls with colorectal malignancies worked in asbestos jobs than other control subjects (25\% vs. $17 \%$ ). However, exclusion of controls with colorectal cancer from the analysis reduced the asbestos exposure percentage from $18 \%$ to $17 \%$ and did not change subsequent odds ratios calculations.] 
TABLE III. Asbestos-Related Occupations of Hospitalized Cases and Controls, 1981-1991

\begin{tabular}{|c|c|c|c|c|c|c|c|c|}
\hline \multirow[b]{2}{*}{ Asbestos occupation $^{a}$} & \multicolumn{2}{|c|}{ Cases } & \multicolumn{2}{|c|}{$\begin{array}{l}\text { Reported } \\
\text { exposure } \\
\text { to asbestos }\end{array}$} & \multicolumn{2}{|c|}{ Controls } & \multicolumn{2}{|c|}{$\begin{array}{c}\text { Reported } \\
\text { exposure } \\
\text { to asbestos }\end{array}$} \\
\hline & No. & $(\%)$ & No. & $(\%)$ & No. & $(\%)$ & No. & $(\%)$ \\
\hline Automobile mechanic & 39 & 1.4 & 12 & 0.4 & 78 & 1.5 & 21 & 0.3 \\
\hline Building maintenance & 26 & 0.9 & 3 & 0.1 & 33 & 0.6 & 9 & 0.1 \\
\hline Carpenter & 67 & 2.4 & 13 & 0.4 & 86 & 1.6 & 12 & 0.2 \\
\hline Construction worker & 89 & 3.1 & 28 & 1.0 & 182 & 3.4 & 28 & 0.5 \\
\hline Cement tiler & 30 & 1.0 & 8 & 0.3 & 34 & 0.6 & 5 & 0.1 \\
\hline Electrician & 47 & 1.6 & 13 & 0.5 & 75 & 1.4 & 13 & 0.2 \\
\hline Equipment mechanic & 28 & 1.0 & 7 & 0.2 & 40 & 0.8 & 5 & 0.1 \\
\hline Firefighter & 20 & 0.7 & 3 & 0.1 & 24 & 0.5 & 5 & 0.1 \\
\hline Painter & 43 & 1.5 & 7 & 0.2 & 51 & 1.0 & 4 & 0.1 \\
\hline Plumber/pipe fitter & 47 & 1.6 & 25 & 0.9 & 55 & 1.0 & 13 & 0.2 \\
\hline Transportation equipment & 48 & 1.7 & 6 & 0.2 & 78 & 1.5 & 8 & 0.2 \\
\hline Textile operative & 16 & 0.6 & 2 & 0.1 & 32 & 0.6 & 0 & 0.0 \\
\hline Welder & 44 & 1.5 & 9 & 0.3 & 58 & 1.1 & 5 & 0.1 \\
\hline Other asbestos jobs ${ }^{b}$ & 47 & 1.6 & 16 & 0.6 & 48 & 0.9 & 16 & 0.3 \\
\hline
\end{tabular}

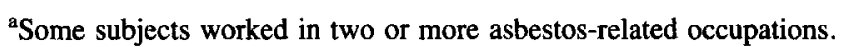

'Includes railroad workers, sheet metal workers, dry cleaners, etc.

Among current smokers, there was no association between employment in asbestos-related occupations and the risk for peripheral or central lung cancers. Among former smokers, there was a significant but small increase in risk for all lung cell types $[\mathrm{OR}=1.3,95 \%$ confidence interval $(\mathrm{CI}) 1.1$ to 1.6$]$, which was attributable largely to 19 cases and nine controls who were employed as sheet metal workers (OR $=4.5$; CI 2.1 to 9.5$)$, and 14 cases and seven controls employed as equipment mechanics ( $\mathrm{OR}=2.3 ; \mathrm{CI} 1.1$ to 4.6$)$.

\section{Reported Exposure to Asbestos Dust}

Over $10 \%$ of cases and $5 \%$ of controls reported occupational exposure to asbestos dust for at least 1 year. The average duration of self-reported exposure was 16 years and 14 years, respectively. No differences in reported asbestos exposure were found between controls with colorectal cancer and other controls. Although employment in asbestos-related jobs was unrelated to case-control status, a greater percentage of cases than controls who worked in asbestos jobs also reported being exposed to asbestos (Table III, $1981-1985 ; 4 \%$ vs. $2.3 \%, 1986-1991 ; 6.6 \%$ vs. $2.3 \%$ ).

Reported exposure to asbestos dust was significantly associated with lung cancer risk. For current smokers, the ORs were significantly elevated for both central and peripheral lung cancers. The OR for all lung cancer cell types was 1.5 (95\% CI 1.1 to 2.1 ) for the period 1980-1985, and 2.5 (95\% CI 1.5 to 4.1 ) for the period 1986-1991. (Table V). The test for trend with the duration of self-reported exposure was not significant. There was a significant association between self-reported asbestos exposure and lung cancer among pipe and cigar smokers (OR $=3.2$; CI 1.2 to 8.5). For ex-smokers, the OR associated with all lung cell types was 1.9 (95\% CI 1.3 to 2.8) for the period 1981 to 1985 and 2.2 (95\% CI 1.4 to 3.5 ) for the period 1986 to 1991.

The ORs for lung cancer among subjects reporting asbestos exposure and who were employed in asbestos occupations may be the most valid measure of asbestos 
TABLE IV. Percent Distribution of Hospitalized Cases and Controls Employed in AsbestosRelated Occupations by Tumor Site, Years of Exposure, and Odds Ratios by Smoking Habits, 1981-1991

\begin{tabular}{|c|c|c|c|c|c|c|}
\hline & \multicolumn{2}{|c|}{ Central lung } & \multicolumn{2}{|c|}{ Peripheral lung } & \multicolumn{2}{|c|}{ Controls } \\
\hline & No. & $(\%)$ & No. & $(\%)$ & No. & $(\%)$ \\
\hline $\mathbf{N}=$ & 305 & 22.6 & 244 & 21. & 936 & 17.9 \\
\hline
\end{tabular}

Duration of employment

$\begin{array}{lllllll}1-8 \text { years } & 26 & 15.3 & 22 & 17.6 & 73 & 24.3 \\ 9-20 \text { years } & 47 & 27.6 & 44 & 35.2 & 75 & 24.9 \\ 21-30 \text { years } & 44 & 25.9 & 23 & 18.4 & 78 & 25.9 \\ >30 \text { years } & 53 & 31.2 & 36 & 28.8 & 75 & 24.9\end{array}$

OR $(95 \% \mathrm{CI}): 1.0(0.9-1.3)$

$$
\text { Ex-smokers }{ }^{b}
$$

$\begin{array}{lrlllrl}1-7 \text { years } & 26 & 20.5 & 16 & 15.0 & 93 & 22.6 \\ 8-20 \text { years } & 26 & 20.5 & 23 & 21.5 & 112 & 27.2 \\ 21-35 \text { years } & 45 & 35.4 & 36 & 33.6 & 110 & 26.7 \\ >35 \text { years } & 30 & 23.6 & 32 & 29.9 & 97 & 23.5 \\ \text { OR }(95 \% \mathrm{CI}): 1.3(1.1-1.6) & & & & & \end{array}$

aOdds ratios for all lung cell types, adjusted for age, education, and cigarettes smoked per day.

bOdds ratios for all lung cell types, adjusted for age, education, and years since quitting smoking.

Referent groups are subjects who were not employed in asbestos-related occupations.

exposure. Persons who neither worked in asbestos occupations nor reported asbestos exposure were used as the referent group. These ORs were calculated only for the study period 1986 to 1990 . The OR for all lung cell types was 2.1 (95\% CI 1.1 to 3.9) for current smokers and 2.4 (95\% CI 1.4 to 4.2$)$ for ex-smokers.

\section{Exposure to Building Insulation}

Table VI shows that 48 of 1,121 cases (4\%) and 52 of 2,093 controls $(2 \%)$ interviewed after 1985 reported a distinct exposure to building insulation for at least 1 year. These subjects were employed as general construction workers and supervisors, carpenters, electricians, roofers, plumbers, heating mechanics, and building maintenance and repair workers. The mean duration of building insulation exposure was 20 years for cases and 17 years for controls. In contrast to cases and controls who were employed in asbestos occupations or who reported asbestos exposure, cases who were exposed to building insulation were much more likely to have ever smoked cigarettes regularly and smoked more cigarettes per day than controls who were exposed to building insulation. The OR for all lung cell types associated with building insulation was 2.2 (95\% CI 1.2 to 4.3 ) for current smokers and 1.8 (95\% CI 0.9 to 3.6) for ex-smokers. No differences in risk were found between central and peripheral lung tumors.

\section{Never Smokers}

Of the 69 cases who never smoked cigarettes, 14 of these were exposed to asbestos (Table VII). Twelve of the 14 cases worked in possible asbestos occupations, 
TABLE V. Percent of Cases and Controls Reporting Exposure to Asbestos Dust, Years of Exposure, and Odds Ratios by Smoking Habits, 1981-1991

\begin{tabular}{|c|c|c|c|c|c|c|c|}
\hline \multirow[b]{3}{*}{ Tumor site } & \multirow[b]{3}{*}{$\mathrm{N}=$} & \multicolumn{2}{|c|}{ Central lung } & \multicolumn{2}{|c|}{$\begin{array}{l}\text { Peripheral } \\
\text { lung }\end{array}$} & \multicolumn{2}{|c|}{ Controls } \\
\hline & & No. & $(\%)$ & No. & $(\%)$ & No. & $(\%)$ \\
\hline & & 149 & 11.1 & 114 & 9.9 & 274 & 5.3 \\
\hline \multicolumn{8}{|c|}{ Current smokers $^{\mathrm{a}}$} \\
\hline \multicolumn{8}{|c|}{ Duration of exposure } \\
\hline $1-3$ years & & 19 & 23.1 & 15 & 22.4 & 23 & 26.7 \\
\hline $4-15$ years & & 21 & 25.6 & 21 & 31.3 & 21 & 24.4 \\
\hline $16-26$ years & & 20 & 24.4 & 15 & 22.4 & 21 & 24.4 \\
\hline$\geq 27$ years & & 22 & 26.8 & 16 & 23.9 & 21 & 24.4 \\
\hline \multirow{2}{*}{\multicolumn{6}{|c|}{ OR $(95 \%$ CI): $1981-1985: 1.5(1.1-2.1) \quad 1986-199$}} & & \\
\hline & & & & & & & \\
\hline $1-3$ years & & 15 & 25.0 & 8 & 21.6 & 31 & 27.2 \\
\hline 4-9 years & & 8 & 13.3 & 8 & 21.6 & 25 & 21.9 \\
\hline $10-19$ years & & 20 & 33.3 & 4 & 10.8 & 28 & 24.6 \\
\hline$\geq 20$ years & & 17 & 28.3 & 17 & 45.9 & 30 & 26.3 \\
\hline \multicolumn{8}{|c|}{ OR $(95 \%$ CI): $1981-1985: 1.9(1.3-2.8) \quad 1986-1990: 2.2(1.4-3.5)$} \\
\hline
\end{tabular}

aOdds ratios for all lung cell types, adjusted for age, education, and cigarettes smoked per day.

bOdds ratios for all lung cell types, adjusted for age, education, and years since quitting smoking.

Referent groups are subjects who did not self-report exposure to asbestos.

including three automobile mechanics, one production line mechanic, two carpenters, two cement workers, two firefighters, a plumber, and an electrician. Eight of these 14 cases reported exposure to asbestos. The two cases who did not work in an asbestosrelated job but did report exposure to asbestos were an entertainer and a school teacher, respectively. The teacher stated that his school had undergone an asbestos abatement program, although he seemed unsure as to the extent of his exposure. The OR for all lung cell types among nonsmoking subjects who reported exposure to asbestos was 2.0 (95\% CI 0.9 to 4.3 ). A separate OR was not calculated for overall employment in asbestos-related occupations among never smokers since the types of asbestos jobs were dissimilar between nonsmoking cases and nonsmoking controls. The ratio of peripheral to central lung tumors was similar for the 14 asbestos-exposed cases (10/2) and unexposed cases (43/13).

\section{DISCUSSION}

The studies conducted by Selikoff and others showed that inhalation of asbestos fibers greatly increases the already high risk of lung cancer for current cigarette smokers (Table I). Most of these studies were conducted in specific occupational settings which had high levels of airborne asbestos. Our data on self-reported insulation and self-reported asbestos exposure suggest that exposure to asbestos also increases the risk of lung cancer among smokers employed in other types of occupations such as general construction, welding, and automobile mechanics. The lung cancer risk was elevated for all sites within the male lung, although there was no trend 
TABLE VI. Percent Distribution of Hospitalized Subjects Reporting Exposure to Building Insulation by Tumor Site, Years of Exposure, and Odds Ratios by Smoking Habits, 1986-1991

\begin{tabular}{|c|c|c|c|c|c|c|}
\hline & \multicolumn{2}{|c|}{ Central } & \multicolumn{2}{|c|}{ Peripheral } & \multicolumn{2}{|c|}{ Controls } \\
\hline & No. & $(\%)$ & No. & $(\%)$ & No. & (\%) \\
\hline $\mathbf{N}=$ & 21 & 4.3 & 21 & 4.1 & 52 & 1.8 \\
\hline
\end{tabular}

Current smokers

Duration of exposure to building insulation

$\begin{array}{lllllll}1-5 \text { years } & 2 & 11.8 & 3 & 23.1 & 4 & 26.7 \\ \text { 6-15 years } & 4 & 23.5 & 3 & 23.1 & 3 & 20.0 \\ 16-28 \text { years } & 4 & 23.5 & 2 & 15.4 & 4 & 26.7 \\ \geq 29 \text { years } & 5 & 29.4 & 5 & 38.5 & 3 & 20.0\end{array}$

OR $95 \% \mathrm{CI}^{\mathrm{a}}: 2.2(1.2-4.3)$

Ex-smokers

$\begin{array}{llrlrll}1-10 \text { years } & 2 & 33.2 & 4 & 57.1 & 6 & 27.3 \\ 11-17 \text { years } & 1 & 16.7 & 0 & 0.0 & 5 & 22.3 \\ 18-30 \text { years } & 0 & 0.0 & 1 & 14.3 & 6 & 27.3 \\ \geq 31 \text { years } & 3 & 50.0 & 2 & 28.6 & 5 & 22.3\end{array}$

OR $95 \% \mathrm{CI}^{\mathrm{a}}: 1.8(0.9-3.6)$

${ }^{\mathrm{a}} \mathrm{OR}$ for all lung cell types, adjusted for age, education, and number of cigarettes smoked per day. Referent groups are subjects who were exposed to neither insulation nor asbestos.

in the ORs with the duration of reported asbestos exposure among current smokers. Few studies have examined asbestos exposure and lung cancer according to histological type of tumor. One case series of 855 lung cancer patients found that $49 \%$ of squamous cell cases and $15 \%$ of adenocarcinomas were occupationally exposed to asbestos [Auerbach et al., 1984]. In a Japanese case-control study of lung cancer, an OR of 3.4 was found for "Kreyberg" I cancer (squamous, large, and oat cell carcinoma), and an OR of 1.7 was found for "Kreyberg" II (adenocarcinoma and others) cancers [Minowa et al., 1991]. Our results show an increased risk for all lung cancer cell types with reported asbestos exposure.

Among former cigarette smokers, the OR associated with self-reported asbestos exposure was greater than that for current smokers. Former smokers may have stopped smoking because of lung cancer symptoms or other respiratory problems and thus may have had the highest exposure to asbestos. Hammond et al. reported mortality ratios of 1.48 for smokers of one or more packs a day who had quit for 5-9 years, and 1.38 for those who quit for at least 10 years [Hammond et al., 1979]. These data and ours suggest that the carcinogenic effect of asbestos persists after smoking cessation and that projections of future incidence of lung cancer attributable to asbestos need to account for the asbestos experience of former cigarette smokers.

Self-reported asbestos exposure can be affected by recall or wish biases [Wynder et al., 1990]. In case-control studies, cases may be more likely to explain their illnesses from an exposure to some substance which occurred unavoidably rather than from an exposure which occurred from personal choice, such as smoking. In a 
TABLE VII. Characteristics of Cases Who Reported to Have Never Smoked Cigarettes and Were Exposed to Asbestos, 1981-1991

\begin{tabular}{|c|c|c|c|c|c|}
\hline Occupation & Age & $\begin{array}{c}\text { Years } \\
\text { employed }\end{array}$ & $\begin{array}{c}\text { No. years } \\
\text { reported } \\
\text { exposure } \\
\text { to } \\
\text { asbestos }\end{array}$ & $\begin{array}{c}\text { Other } \\
\text { exposures }\end{array}$ & $\begin{array}{l}\text { Site of } \\
\text { lung } \\
\text { cancer }\end{array}$ \\
\hline auto mechanic & 63 & 31 & - & grease, gas fumes & central \\
\hline auto mechanic & 46 & 17 & 2 & gas, fumes, and exhaust & central \\
\hline auto mechanic & 43 & 15 & 15 & chemicals, acids & peripheral \\
\hline carpenter & 66 & 39 & $22^{\mathrm{a}}$ & wood dust & peripheral \\
\hline carpenter & 51 & 24 & 4 & wood dust & peripheral \\
\hline cement tiler ${ }^{b}$ & 69 & 15 & - & chemicals & peripheral \\
\hline cement tiler & 50 & 28 & 28 & chemicals & peripheral \\
\hline electrician & 60 & 41 & - & grease & NOS ${ }^{c}$ \\
\hline firefighter & 72 & 48 & - & - & peripheral \\
\hline firefighter & 31 & 4 & - & diesel fumes & NOS \\
\hline plumber/pipe & 60 & 20 & - & metal dust & peripheral \\
\hline transp. mechanic & 53 & 10 & - & - & peripheral \\
\hline entertainer & 55 & n.a. & 10 & stone dust & peripheral \\
\hline teacher & 60 & n.a. & 1 & - & peripheral \\
\hline
\end{tabular}

${ }^{\text {a }}$ Years reported exposed to insulation.

${ }^{\mathrm{b}}$ This case also worked in a shipyard for 4 years and reported exposure to asbestos.

${ }^{\mathrm{c}}$ Not otherwise specified. For 69 nonsmoking cases not exposed to asbestos, there were 24 professional and kindred workers, 13 public and private managers, 15 sales and clerical workers, 10 skilled craftsworkers, and seven semiskilled workers. Thirteen had central lung cancers, 43 had peripheral lung cancers, and 13 had other or unknown histologies.

previous study of diesel exhaust exposure and lung cancer risk, we found a trend with duration of self-reported exposure but none with most occupations involving probable exposure to diesel exhaust [Boffetta et al., 1989]. For subjects interviewed after 1985,75 of 336 cases (22\%) who were employed in asbestos-related occupations had reported asbestos exposure, compared to 57 of 555 controls (10\%). Hypothetically, if only 40 of the 336 cases $(12 \%)$ reported asbestos exposure when none had occurred, then correcting for this nonrandom misclassification would result in equal exposure percentages between cases and controls. Under this circumstance, the data suggest that the levels of asbestos exposure in such jobs as general construction and carpentry would not appear to increase a smoker's risk of lung cancer.

It should be noted, conversely, that 75 of 121 cases (62\%) and 62 of 93 controls (67\%) who self-reported asbestos exposure had worked in asbestos-related jobs. Similarly, $74 \%$ of both cases and controls reporting exposure to insulation had worked in jobs with likely asbestos exposure. Of the 46 cases not employed in occupations with likely asbestos exposure, $39(85 \%)$ had worked in jobs with at least possible asbestos exposure, including laborers, machine operatives, a civil and a nuclear engineer, janitors-custodial engineers, a gaffer, and military personnel. An example of a military job that entails working with asbestos is marine engine room work [Lilienfeld et al., 1988]. Among the seven other cases who were not employed 
in asbestos occupations, four reported exposure from their worksite buildings, including two police officers (police stations), a paper handler (printing press), and a store owner. A truck driver reported that he had regularly picked up asbestos as part of his job responsibilities. Two cases did not specify the source of their exposure.

Of the 29 exposed controls who were not employed in jobs with likely asbestos exposure, $22(76 \%)$ had worked in jobs with at least possible exposure and four reported exposure from their worksites, including a judge (courtroom), two business owners (automotive and carpentry shops), and a real estate agent (property maintenance). Three controls did not specify the source of their exposure.

In contrast to the findings on self-reported asbestos exposure, most occupations that were classified as asbestos-related were not predictive of lung cancer risk. Significant differences were found for a small number of specific job titles, although this might reflect chance findings resulting from multiple comparisons. Job titles alone may be an inadequate criteria for assessing asbestos exposure in case-control studies of lung cancer for several reasons. We did not have information on the intensity of asbestos exposure, and fiber type, shape, and exposure regimen. The concentrations of airborne asbestos fibers vary considerably in different occupations, and the asbestos risk of lung cancer varies by occupation. For example, textile workers, shipyard workers, and insulators have a higher mortality from lung cancer than most other asbestos cohorts that have been studied [McDonald and McDonald, 1987]; the experience for many asbestos workers is not as well documented. Persons exposed to occupational or environmental asbestos at levels hundreds of times below that found in some workplace conditions have been found to have no increased risk for lung cancer [Ohlson and Hogstedt, 1985]. In our data, there was a wide range of occupations among those considered asbestos-related, although there was only one shipyard worker and no asbestos miners and millers.

It seems likely that among the subjects who reported to be occupationally exposed to asbestos, the intensity of the exposure must have been sufficiently high to have been recognized and reported. For subjects who worked in asbestos-related occupations but did not report any exposure, occupational levels of asbestos were likely to have been low. Even within specific job categories, there is substantial variation in exposure. For example, motor vehicle mechanics were considered to be exposed to asbestos, although only brake liners may actually inhale substantial concentrations of airborne asbestos.

Many of the occupations that were considered as having likely asbestos exposure were based on studies of malignant mesothelioma. However, Lilienfeld et al. [1988] point out that occupations identified as involving asbestos exposure based on studies of mesothelioma incidence may not necessarily be at high risk for lung cancer, especially since the extent to which different levels of asbestos interact with cigarette smoking in the development of lung cancer is unknown. Asbestos exposure may also occur from other sources besides the workplace, including domestic exposure from relatives employed in asbestos occupations, household renovations, hobbies, and environmental sources. On the other hand, there are other lung carcinogens in some asbestos-related occupations. Fire fighters are exposed to smoke containing polycyclic aromatic hydrocarbons and welders are exposed to nickel dust and chromium.

The control group in this study included some patients with colorectal cancer. In a review of the epidemiologic literature, Weiss [1990] concluded that asbestos was not associated with gastrointestinal (GI) malignancies. In contrast, a meta-analysis 
conducted by Frumkin and Berlin [1988] showed a significant relationship between asbestos exposures and GI cancers. When the colorectal cancer patients were excluded from our analysis, the relative risk estimates were unaffected.

Perhaps the most valid measure of asbestos exposure was the category of subjects who both reported exposure to asbestos and were employed in asbestos-related jobs. The odds ratios for this group were very similar to the ORs found for reported insulation and reported asbestos exposure only.

There is little epidemiologic information on the asbestos risk of lung cancer for never smokers (Table I). Nearly all employees of asbestos occupations in studies of lung cancer have been smokers and risk estimates for nonsmokers have been based on very small numbers. Of the 14 nonsmoking lung cases who were employed in asbestos-related occupations in our study, there were nine distinct occupations. Most of these 14 cases were also exposed to other chemicals or irritants which may affect the lung. When examining the risk by reported exposure to asbestos, there was an elevated but nonsignificant association ( $O R=2.0,95 \% \mathrm{CI} 0.9$ to 4.3 ). Although this OR was based on only eight nonsmoking asbestos-exposed workers, this number is more than the number of nonsmoking asbestos-exposed cases reported in previous studies. Still, this OR and those reported in other studies should be interpreted with caution. Misclassification of self-reported smoking habits is uncommon although it does occur in epidemiologic studies of lung cancer, especially for long-term exsmokers [Lee, 1987]. Even if a very small percentage of smoking subjects was misclassified as nonsmokers, the lung cancer risk for nonsmokers would be substantially biased. In addition, one needs to keep in mind that other carcinogens may have caused these lung cancers.

\section{ACKNOWLEDGMENTS}

We thank Edward S. Garrity, Jr., MD, Loyola University Hospital, Chicago, IL; John Sharp, MD, Hines Veterans Hospital, Hines, IL; Christine Johnson, PhD, Henry Ford Hospital, Detroit, MN; Kanti R. Rai, MD, Long Island Jewish Hillside Medical Center, New Hyde Park, NY; Elliot Strong, MD, and Newton Morton, MD, Memorial Sloan-Kettering Cancer Center, New York, NY; Linga Ragu, MD, Nassau County Medical Center, East Meadow, NY; James E. Colberg, MD, Thomas Jefferson University Hospital, Philadelphia, PA; and Paul Stolley, MD, Hospital of the University of Pennsylvania, Philadelphia, PA. We also thank Drs. Gary Williams and John Whysner of American Health Foundation for expert comments. This work was supported by U.S. Public Health Service Grants CA-32617 and CA-17613 from the National Cancer Institute.

\section{REFERENCES}

Acheson ED, Gardner MJ, Winter PD, Benett C (1984): Cancer in a factory using amosite asbestos. Int J Epidemiol 13:3-10.

Auerbach O, Garfinkel L, Parks VR, Conston AS, Galdi VA, Joubert L (1984): Histologic type of lung cancer and asbestos exposure. Cancer 54:3017-3021.

Berry G, Newhouse ML, Antonis P (1985): Combined effect of asbestos and smoking on mortality from lung cancer and mesothelioma in factory workers. Br J Ind Med 42:12-18. 
Blot WJ, Harrington JM, Toledo A, Hoover R, Heath CW, Fraumeni JF (1978): Lung cancer after employment in shipyards during World War II. N Engl J Med 299:620-624.

Blot WJ, Morris LE, Stroube R, Tagnon I, Fraumeni JF (1980): Lung and laryngeal cancer in relation to shipyard employment in coastal Virginia. J Natl Cancer Inst 65:571-575.

Boffetta P, Harris RE, Wynder EL (1989): Diesel exhaust exposure and lung cancer risk. Exp Pathol $37: 1-4$.

Department of Labor, Occupational Safety and Health Administration (1990): "Occupational Exposure to Asbestos, Tremolite, Anthophyllite and Actinolite, Proposed Rule." Federal Register, Part II, 29 CFR Parts 1910 and 1926. Washington, D.C: July 20, 1990.

Devesa SS, Shaw GL, Blot WJ (1991): Changing patterns of lung cancer incidence by histological type. Cancer Epidemiol, Biomarkers, Prev 1:29-34.

El-Torky M, El-Zeky F, Hall JC (1990): Significant changes in the distribution of histological types of lung cancer. Cancer 65:2361-2367.

Frumkin H, Berlin J (1988): Asbestos exposure and gastrointestinal malignancy: Review and metaanalysis. Am J Ind Med 14:79-95.

Hammond EC, Selikoff IJ, Seidman H (1979): Asbestos exposure, cigarette smoking and death rates. Ann NY Acad Sci 330:473-490.

Lee PN (1987): Lung cancer and passive smoking: Association an artefact due to misclassification of smoking habits? Toxicol Lett 35:157-162.

Lilienfeld DE, Mandel JS, Coin P, Schuman LM (1988): Projection of asbestos related diseases in the United States, 1985-2009. I. Cancer. Br J Ind Med 45:283-291.

Mancuso TF (1983): Mesothelioma among machinists in railroad and other industries. Am J Ind Med 4:501-513.

Martischnig KM, Newell DJ, Barsnsley WC, Cowan WK, Feinman EL, Oliver E (1977): Unsuspected exposure to asbestos and bronchogenic carcinoma. Br Med J 1:746-749.

McDonald AD, McDonald JC (1980): Malignant mesothelioma in North America. Cancer 46:16501656.

McDonald JC, McDonald AD (1987): Epidemiology of asbestos-related lung cancer. In: Antman K, Aisner J (eds): “Asbestos-Related Malignancy." Orlando, FL: Grune \& Stratton, pp 57-79.

Minowa M, Hatano S, Ashizawa M, Ogura H, Naruhashi H, Suzuki M, Mitoku K, Miwa M, Wakamatsu C, Yasuda Y, Shirai K, Miura H (1991): A case-control study of lung cancer with special reference to asbestos exposure. Environ Health Perspect 94:39-42.

Morabia A, Wynder EL (1991): Cigarette smoking and lung cancer cell types. Cancer 68:2074-2078.

Muscat JE, Wynder EL (1991): Cigarette smoking, asbestos exposure and malignant mesothelioma. Cancer Res 51:2263-2267.

Nicholson WJ, Perkel G, Selikoff IJ (1982): Occupational exposure to asbestos: Population at risk and projected mortality-1980-2030. Am J Ind Med 3:259-311.

Ohlson CG, Hogstedt C (1985): Lung cancer among asbestos cement workers: A Swedish cohort study and a review. Br J Ind Med 42:397-402.

Pastorino U, Berrino F, Gervasio A, Pesenti V, Riboli E, Crosignani P (1984): Proportion of lung cancers due to occupational exposure. Int J Cancer 33:231-237.

Quinn MN, Kriebel D, Buiatti E, Paci E, Sini S, Vannucchi G, Zappa M (1987): An asbestos hazard in the reprocessed textile industry. Am J Ind Med 11:256-266.

Rodelsperger K, Jahn H, Bruckel B, Manke J, Paur R, Woitowitz HJ (1986): Asbestos dust exposure during brake repair. Am J Ind Med 10:63-72.

Rubino GF, Piolatto G, Newhouse ML, Scansetti G, Aresini GA, Murray R (1979): Mortality of chrysotile asbestos workers at the Balangero Mine, Northern Italy. Br J Ind Med 36:187-194.

SAS User's Guide (1985): "Statistics. Version 5." Cary, NC: SAS Institute.

Schenker MB, Garshick E, Munoz A, Woskie SR, Speizer FE (1986): Mesothelioma among machinists in railroad and other industries. Am J Ind Med 134:461-465.

Selikoff U, Seidman H, Hammond EC (1980): Mortality effects of cigarette smoking among amosite asbestos factory workers. J Natl Cancer Inst 65:507-513.

Talcott JA, Thurber WA, Kantor AF, Gaensler EA, Danahy JF, Antman KH, Li Pl (1989): Asbestosassociated diseases in a cohort of cigarette-filter workers. N Engl J Med 321:1220-1223.

Teta MJ, Lewinsohn NC, Meigs JW, Vidone RA, Mowad LZ, Flannery JT (1983): Mesothelioma in Connecticut, 1955-1977. J Occup Med 25:749-756. 
Weiss W (1990): Asbestos and colorectal cancer. Gastroenterology 99:876-884.

Wynder EL, Higgins I, Harris RE (1990): The wish bias. J Clin Epidemiol 43:619-621.

Young I, Weit S, Jackson J, Cantrell P (1981): Prevalence of asbestos-related lung disease among employees in non-asbestos industries. Med J Aust 1:464-467. 